\title{
Mediator Complex
}

National Cancer Institute

\section{Source}

National Cancer Institute. Mediator Complex. NCI Thesaurus. Code C19864.

A protein complex that is involved in the initiation of transcription. This complex is composed of over 30 protein subunits, which binds to the RNA polymerase II holoenzyme complex and facilitates the interaction of transcription factors with the polymerase. 